Article

\title{
Government and Intermediary Business Engagement for Controlling Electronic Waste in Indonesia: A Sustainable Reverse Logistics Theory through Customer Value Chain Analysis
}

\author{
Hesti Maheswari*D, Gatot Yudoko and Akbar Adhiutama \\ School of Business and Management, Institut Teknologi Bandung, Bandung 40132, Indonesia; \\ gatot@sbm-itb.ac.id (G.Y.); akbar@sbm-itb.ac.id (A.A.) \\ * Correspondence: hesti.maheswari@sbm-itb.ac.id; Tel.: +62-821-2359-6058; Fax: +62-22-2504249
}

Received: 27 November 2018; Accepted: 28 January 2019; Published: 30 January 2019

\begin{abstract}
Environmental pollution caused by the improper processing of electronic waste, especially from mobile phones, has increased drastically. Governments in developing countries, including Indonesia, have not been ready to face this problem. Informal groups are reacting very fast, growing and spreading evenly in many places to profit through reverse logistics activities. They dominate the markets of used electronic products. Today, eradicating these groups is impossible due to poverty, low education, and unemployment problems. Competing with them is also useless. Therefore, this research aims to find an engagement model between government and intermediary businesses, both formal and informal, for a sustainable purpose. Before determining the model, we must understand the intermediary businesses' expectations. Therefore, we interviewed eight respondents that represent each business group and used customer value chain analysis to map them. We found forty-one expectations. Seven are the most common but are difficult to realize since they contradict government regulations. To cope with the urgency of the current situation, we concluded that the government should engage directly with the needs of these businesses, and we recommend three models of engagement i.e., empowerment, collaboration, and involvement.
\end{abstract}

Keywords: customer value chain analysis; electronic waste; Indonesia; sustainable reverse logistics; waste management

\section{Introduction}

The quantity of mobile phone waste has increased significantly in line with the dramatic sales of cellphones [1,2]. According to Gartner research, this quantity increased by 1.3 percent in 2018 [3]. In the first quarter of 2018, Gartner research noted 455 million smartphones in Indonesia were sold. This number is almost twice the size of the total population of Indonesia. The rapid growth of mobile phone sales is caused by consumers' consumptive behavior [4-6], economic growth, rapid technological development and innovations, and rapid changes in information and communication technology. However, prices remain affordable [1,7]. Unfortunately, most consumers in Indonesia use cell phones for less than 3 years, especially if they use other electronic devices [6,8]. More than 20 million mobile phones are predicted to be discarded by the end of this year [2]. Hence, it is not surprising if mobile phone products make the greatest and fastest contribution to electronic waste (e-waste) [2]. The four major challenges causing e-waste problems are worsening, namely, poor education and environmental awareness, lack of appropriate recycling technology, lack of incentives for collecting and recycling initiatives [1], and poor funding and environmental regulatory authorities [7-9]. 
Although cell phones are abundant, they are very difficult to locate and collect, seeming to disappear from circulation [5]. In addition to the lack of communities' awareness, the disappearance of e-waste from circulation is caused by the significant income-generating activities of informal business groups, such as scavengers, junkmen, stalls/kiosks, dealers, and local smelters [9]. These groups take advantage of government negligence to reap a profit through various reverse logistics (RL) activities (dismantling, refurbishing, recycling). They often ignore the harmful environmental consequences of their actions that results from their lack of high-technology equipment and skillful human resources to process the e-waste into a valuable product [10]. They operate their businesses manually $[5,9,10]$, and are forced to operate for survival since they have no other source of financial power.

The number of informal businesses is very large and evenly distributed throughout the regions of Indonesia, including those of Java island, such as Jakarta and West Java [11]. They operate clandestinely since they know that their activities often cause damage and the government forbids them [10]. An actual case of environmental violation caused by informal business activities in Indonesia is the heavy metal contamination case in Ciampea-Bogor that caused mental disorders of toddlers, as well as paralysis and death [12]. Most people in this area conducted manual accumulator reconditioning, one of the RL activities, as their main job. They knew that this activity was dangerous for them and the environment, but undertook it nonetheless since they did not have other alternatives to earn a living $[5,6,9,10]$. We witnessed that there were many people conducting RL activities who disregarded the pollution they produced $[1,6,7,9,10]$, despite one of the goals of conducting RL activities being environmental preservation. Such results call for immediate attention from policymakers and research communities. We are convinced that RL terminology is insufficient to be used and implemented in developing countries. We must give emphasis to sustainable concepts in RL activities and propose sustainable reverse logistics (SRL) terminology [5] for research in the area of environmental conservation, to anticipate the uninformed behavior $[4,5]$, to ensure that all activities in the reverse value chain refer to sustainability goals, and to balance all expectations.

In addition to informal businesses, some formal (legal) businesses, either traditional or international waste management companies, also process e-waste into other valuable products. They conduct their operations safely but have difficulty finding mobile phone waste. It is also impossible for them to collect mobile phone waste from households door-to-door as is done by informal businesses. They only receive waste electrical and electronic equipment (WEEE) and rejected products from producers or institutions for recycling. In this research, these two business types (informal and formal) are referred to as intermediary businesses.

Recently, the government has tried to ban the illegal operation of informal businesses $[9,10]$, however, this action was poorly structured, unproperly coordinated, and not taken seriously [5]. Eradicating informal businesses is also impossible to execute by governments in developing countries because they are recognized as playing an important role in the collecting, separating, and dismantling processes [9], and their existence helps in collecting e-waste. They must be engaged [13] and embraced to overcome the e-waste problem and environmental pollution rather than be eradicated. We must find the engagement types to suit them. Before determining the form of engagement, firstly we must understand their expectations. Therefore, this study started by capturing the intermediary business expectations when operating in the reverse chain. Considering these business expectations and matching them with government regulations is not an easy matter, so it will be the first agenda in this paper. We propose that it can be a new measurement of sustainable reverse logistics performance and a guideline for controlling business activities in reverse chains for developing countries.

The rest of this paper is organized as follows. The Section 2 explores the literature related to sustainable reverse logistics and engagement theory. Section 3 discusses the research method, including the research process, samples, data collection, and interview guidelines. Section 4 explains the main findings, i.e., intermediary businesses expectations, and proposes the specific engagement models between government and intermediary business. Finally, Section 5 summarizes the research findings for suggesting further research. 


\section{Literature Review}

\subsection{Sustainable Reverse Logistics}

RL is a set of activities to recapture value from used electronic, broken, and failed products in order to recover their assets [5], while sustainability is a set of skills and concepts that allow businesses to obtain competitive returns without sacrificing people and environmental interests [14]. Joining the definitions of reverse logistics and sustainability brings about sustainable reverse logistics (SRL) [5]. In the SRL concept, a business must not only control financial achievements, but must also consider its impact on the economy as a whole, the environment, and the social conditions, which conforms to the quattro bottom line (QBL) approach: planet, people, profit, [14,15] and reputation [5], as presented in Figure 1. The QBL concept emphasizes the concepts of (1) economy (decreasing the use of raw materials, reducing disposal costs, creating added value for end-of-life products, and demonstrating environmentally responsible behavior), (2) legal (implementing extended producer responsibility), (3) social (preventing environmental pollution from carbon emission and e-waste generation) [14-16], and (4) reputation (maintaining the behavior towards the environment) $[5,6]$.

Government

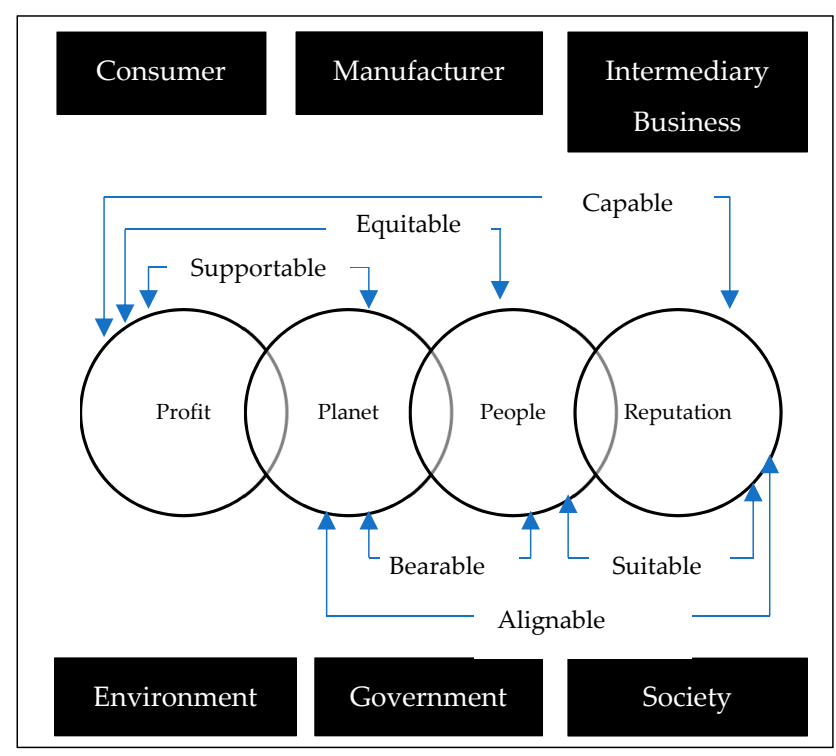

Government

Figure 1. Quattro bottom line approach for sustainable reverse logistics theory [6].

The QBL approach can be implemented into SRL activities through conducting eight types of activities, i.e., remanufacturing, reconditioning, refurbishing, re-processing, repairing, recycling, reusing, disassembling, and disposing $[17,18]$. However, our research only found six of the above and two additional types have commonly be undertaken in Indonesia, i.e., smelting, and exporting [5]. Further, this approach was integrated in a circular business model (CBM) considering circular economy (CE) principles [19], i.e., (1) value proposition in the form of extended duration, product-service system, and customer incentive for bringing back used electronic goods [1]; (2) customer responsibility in consuming electronic goods by maximizing utilization; (3) possible virtualization to increase efficiency; (4) customer relationship for serving in a long period; (5) revenue stream comprising payments for circular products or services; (6) key resources with better performance; (7) sound performance in each key activity and more eco-friendly; (8) good partnership; (9) appropriate distribution of economic costs and benefits among actors; (10) take-back system through keeping materials in a closed loop; and (11) organizational capabilities and external factors to support CBM. 
For balancing the four elements in the QBL concept (3PR) and conforming to CBM, we used these six constructs, namely, supportable, equitable, capable, bearable, alignable, and suitable [5]. Supportable indicates that reverse logistics activities generate business and economic opportunities, as well as provide environmental benefits through renewable and reusable resources as materials in an efficient way. Equitable reflects the ability of businesses to generate a return besides creating new jobs and additional income for communities. Capable delineates the positive image of businesses from each stakeholder since they are able to maximize resources used by maintaining, repairing, and upgrading a product. Bearable demonstrates the ability to maintain global health by preserving the environment. Alignable describes the balance between sound business reputation achievement and environmental conservation through SRL activities. Suitable shows the harmony of social welfare and a sound business reputation if SRL activities are conducted. These constructs will be the basis of the balanced management of mobile phone waste so that it does not harm other parties.

Balancing the various interests needs sound regulations [20,21]. In many developing countries, especially Indonesia, designing sound regulation for managing e-waste is a big problem for a number of reasons. First, the government does not understand the interest of each stakeholder [5]. Second, unclean government management [10] makes regulation profitable only for some parties. Third, there is significant friction between government agencies. For example, the policy of the Ministry of Environment and Forestry to reduce plastic usage is contrary to the policy of the Ministry of Industry that pushes plastic industries to increase their production. Therefore, the CE principle is needed for balancing economic, ecological, and social needs [19]. All stakeholders are partners in the reverse chains which must be considered. How the CE principle can be applied to a business model is the last agenda in this paper. To avoid determining an inappropriate model of cooperation among these stakeholders, we need to discuss engagement theory.

\subsection{Engagement Theory}

In determining a level of engagement, the nature of the relationship and type of communication needs to be defined. In addition, the method of engagement should be selected according to the needs, capacities, and expectations of the relevant stakeholders. Figure 2 describes the different level and approach of engagement based on the type of communication and the nature of relationship [22]. The owners of engagement should involve stakeholders in the design and implementation of the engagement purpose and scope. Based on network theory, the nature of stakeholder relationships in the reverse chain must be based on long-term trust, a high level of engagement, and diverse communication [23]; thus, the appropriate types of engagement are involvement, collaboration, and empowerment.

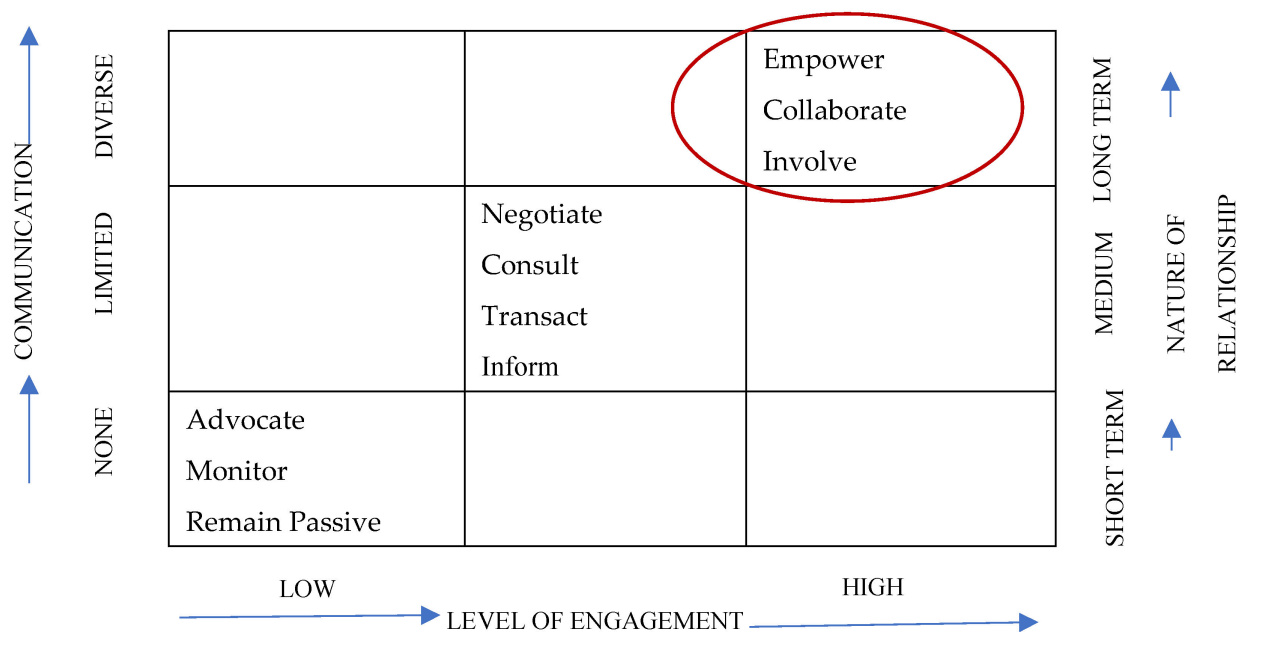

Figure 2. Different levels of engagement [22]. 


\subsubsection{Involvement}

"Participation or involvement is defined as the involvement of a person either mentally or emotionally that encourages him or her to contribute to group" [24]. Social participation has been defined as "a process in which individuals take part in decision making in the institutions, programs, and environments that affect them" [24]. Wilcox [25] identified five levels of participation relating to the stance of an organization in promoting participation, namely: information-merely telling people what is planed; consultation-offering some options, listening to feedback, but not allowing new ideas; deciding together-encouraging additional options and ideas, and providing opportunities for joint decision making; acting together-in addition to interests deciding together, they also form a partnership to carry out the decisions; and, support independent community interest-local groups or organizations which are offered funds, advice or other support to develop their own agendas.

\subsubsection{Collaboration}

The collaboration model is used to simplify the complexity of relationships and inter-organizational interaction [26]. Collaboration between organizations is supported by many factors, i.e., trust between the parties, effective communication, interpersonal relations, and leadership. There are at least six issues in processing collaboration between organizations [27], namely: managing aims; compromise; communication; language; democracy and equality; power and trust; and determination, commitment, and stamina. In collaboration, all parties work together and build a consensus to reach a decision that results in benefits to them. The relationship between the parties is ongoing and therefore collaboration is dynamic and interdependent. As a dynamic concept, collaboration is an incremental process through several stages [28], namely: (1) the floating vision of collaboration that explains the common interest; (2) approaches to visioning in the form of equalization of understanding and collective experience documented in the form of operating principles as a reference to how stakeholders work; (3) appreciative inquiry, a tool to find a better, more effective and constructive way; and (4) discovery (finding the best), dream (vision wish generated), design (visible proposal), and delivery (application of design).

\subsubsection{Empowerment}

The key issues of empowerment are a new form of accountability, with decisions delegated to stakeholders, and stakeholders playing a role in shaping the organizational agenda [21]. The methods of engagement are an integration of stakeholders into governance, strategy, and operations of the organization. For example, the Chinese government tackled waste mobile phone problems by engaging communities through empowerment programs, such as the green box program, recycling old-for-new activities, willingness to pay [29], regulation of consumers' economic responsibility, and awareness [27]. Not only communities but also businesses must have an active role $[10,28]$.

\section{Materials and Methods}

In order to achieve the two research goals-identifying intermediary business expectations as part of SRL activities and how to engage them with government-we used customer value chain analysis (CVCA). CVCA is a tool that is able to identify relevant stakeholders, their relationships, and their roles in the product life cycles to formulate product definitions [13]. We interviewed the selected respondents that represent each position in e-waste circulation. Meanwhile, government expectations, rules and policies in SRL implementation were obtained from a previous study. For a clear explanation, we present the research flows, detail of respondents, and interview guidelines in this subsection. In the second step, we will propose the engagement model between the actors. 


\subsection{Research Flow and Respondents}

This research flow is divided into three steps. The first step involves collecting initial data by interviewing one actor at each level of mobile phone waste circulation. This step aims to gather opinions about e-waste management in Indonesia. To maintain accuracy, this research used snowball sampling to determine the respondent. Snowball sampling is used when it is difficult to identify members of the research population as potential participants [30]. We chose the Head of Sub-directorate Specific and Recycled Waste, Directorate of Waste Management, the Ministry of Environment and Forestry as the first respondent. We obtained eight recommended respondents with various backgrounds and positions from the first respondent (i.e., directors of operations and safety, health, environment, and quality assurance (SHEQ) in international waste management companies (R1), directors and owners of traditional waste management companies (R2), dealers (R3), kiosks/stalls (R4), exporters (R5), local smelters (R6), retailers (R7), and service and repair representatives (R8). The key respondent believed this study will collect valid data since all of the respondents have been in business for more than 10 years. From this data, we carried out a further analysis to obtain three outputs: (1) an important construction that illustrates the expectations of all stakeholders, (2) the balance of relationships from these expectations (constructs), and (3) the number of actors who must be involved.

The second step involves formulating the needs and values of the intermediary business and government using customer value chain analysis (CVCA). For using CVCA, this research used the four guidelines [13], i.e., defining the initial business model and assumption, delineating the pertinent parties involved in the product, determining how the parties are related to each other, and identifying the relationships among the parties by defining the flows between them. The third step proposes an engagement model between government and intermediary business for implementing SRL as an effort to reduce environmental pollution through SRL activities. As will be seen, we developed at least eight different types of engagement between government and intermediary businesses.

\subsection{In-Depth Interview Guidelines}

The interview guidelines are designed by regarding who the respondents are. As explained above, we have two groups of respondents. i.e., formal and informal businesses. Basically, we asked them about their expectations in running their businesses and their willingness to support the government in protecting the environment through SRL activities, as depicted in Table 1.

Table 1. In-depth interview guideline.

\begin{tabular}{|c|c|c|c|}
\hline Topics & Key Points to be Covered & Key Question to be Addressed & $\begin{array}{l}\text { Literature Review and } \\
\text { Empirical Previous Study }\end{array}$ \\
\hline Business scope & RL activities i & What is your business? & {$[5,9]$} \\
\hline $\begin{array}{l}\text { Motivation and } \\
\text { business principles }\end{array}$ & $\begin{array}{l}\text { Profit, Planet, People, Reputation. } \\
\text { Balancing of QBL }\end{array}$ & $\begin{array}{l}\text { What is the main motivation in running } \\
\text { this business? (business principles) }\end{array}$ & {$[6,9,10]$} \\
\hline $\begin{array}{l}\text { Compliance of safety } \\
\text { equipment usage }\end{array}$ & $\begin{array}{l}\text { Fulfillment of internal and external } \\
\text { safety and health requirement }\end{array}$ & $\begin{array}{l}\text { Do you pay attention to safety and } \\
\text { health requirement for your employee? }\end{array}$ & {$[9,10]$} \\
\hline $\begin{array}{l}\text { Environmental } \\
\text { awareness and } \\
\text { performance }\end{array}$ & $\begin{array}{l}\text { Evidence of concern for the } \\
\text { environment and social health } \\
\text { and harmony }\end{array}$ & $\begin{array}{l}\text { What is the proof that this company } \\
\text { concern with the planet and people? }\end{array}$ & {$[5,6,9,10,17,21,31,32]$} \\
\hline $\begin{array}{l}\text { Strategy in } \\
\text { env. management }\end{array}$ & $\begin{array}{l}\text { Strategy in term of } \\
\text { environmental management }\end{array}$ & What is your business strategy? & {$[7,25,33]$} \\
\hline Challenges & $\begin{array}{l}\text { Problems formulation, why e-waste } \\
\text { business is very difficult to control }\end{array}$ & $\begin{array}{l}\text { What are the obstacles when running } \\
\text { this business? }\end{array}$ & {$[5,6,9,10,17,21]$} \\
\hline Benchmark & $\begin{array}{l}\text { Other alternatives to handle e-waste } \\
\text { problems through SRL implementation }\end{array}$ & $\begin{array}{l}\text { Have you seen how other countries } \\
\text { handle mobile phone waste problems? }\end{array}$ & {$[7,17,28,32,33]$} \\
\hline Expectation & SRL Realization & What are your expectations? & [5] \\
\hline Willingness to cooperate & $\begin{array}{l}\text { Finding the types of engagement to } \\
\text { handle mobile phone waste problem? }\end{array}$ & $\begin{array}{l}\text { How big your willingness to engage in } \\
\text { SRL implementation for handling } \\
\text { this problem? }\end{array}$ & {$[5,6,9,10,34-36]$} \\
\hline
\end{tabular}




\section{Results and Discussions}

This section consists of two main parts following the research objectives. The first part is to capture intermediary business expectations and the second part is to propose an engagement model between government and intermediary businesses in overcoming e-waste problems. For capturing the expectations, firstly, this research will describe the current situation of mobile phone waste circulation. We triangulated data collections as a validity test by interviewing each respondent at least twice starting from March to August 2018 to obtain real and accurate information. By observing the circulation model, we knew that there are eight actors, of both formal and informal groups, that are attempting to benefit in the reverse chain, and whose businesses we wished to understand. Finally, in the second part, these expectations were matched up with government policies, including rules and regulations, as a basis for determining the engagement model between them.

\subsection{The Expectations to Implement Sustainable Reverse Logistics}

\subsubsection{Current Situation of Mobile Phone Waste Circulation}

The intent of this section is to describe WEEE recycling practice, especially for mobile phone waste, and the situation of its circulation (Figure 3). We conducted several initial projects to integrate informal groups into the e-waste management system. We found eight types of activities in the reverse chain; six types are part of RL activities and others (i.e., smelting and exporting) are not included although they are mostly conducted by informal businesses in Indonesia. There are eight actors in the informal group, however, according to the key respondent, six respondents are enough to represent this group. They are a dealer (R3), intermediate (kiosk) (R4), exporter (R5), local smelter (R6), retailer (R7), service and repair (R8). There are only two actors in the formal group, i.e., international (R1) and traditional (R2) waste management company.

We use three different colors for arrows and boxes in Figure 3. Green arrows or boxes reflect a green activity, yellow indicates that each actor must be careful about this activity, and the red color indicates that this activity tends to harm the environment. There are six activities in green boxes, which means that these activities help reduce environmental pollution. The six activities are: (1) disassembling (removing components of the product that cannot be used without damaging other components; the components are then reused and the remainder will be recycled or disposed of). (2) refurbishing (returning a product to an "as new" condition through cosmetic changes, such as minor repairs, new paint, cleaning, stain removal). (3) Reselling as is (using the second-hand product with or without any changes). (4) repairing (replacing damaged parts so the product is reusable). (5) recycling (processing used or damaged electronic products into another product with the same or different function). (6) disposing (hoarding material where material cannot be used anymore) [17]. The selection color of arrows depends on the safety of these activities conducted by businesses. For example, we use the red arrow when recycling activity is conducted by smelters while green arrow is used for formal businesses.

We found other activities in the reverse chain that are not guaranteed to be safe for the environment, i.e., smelting and exporting. Smelting is the process of extracting a metal (gold, aluminum, copper) from its ore by heating beyond its melting point [37]. We use a red color for smelting activity because almost all local smelters (R6) conduct improper smelting process. They do not have adequate human resources and technology, and ignore standard equipment and procedures, so that their activities have adverse impacts, such as air, land, and water pollution, which have negative impacts on societies' health. Lung cancer, tuberculosis, and other cancerous cases are often found in communities that make smelting activities part of their livelihoods [10]. The smelting process requires a large area far from residential areas [9]. Most local smelters in Java Island burn materials in rice fields far from homes. They usually work in a group, in which some are in charge of locating used mobile phones, some are involved in the smelting process, and some act as the land provider. They cannot hide this activity since smoke and odor from the combustion process are impossible to avoid. 
They must cooperate with village officials to get information if there is an inspection due from central government officials. They must spend a lot of money to get protection from village officials. Usually, they pay by gold and copper that they mine. This phenomenon occurs in many places in Indonesia, especially in remote areas. Exporting involves shipping e-waste to another country for future sale, and is one of the alternatives are chosen by dealers, stalls, and smelters if they do not have a large and safe place to burn the materials.

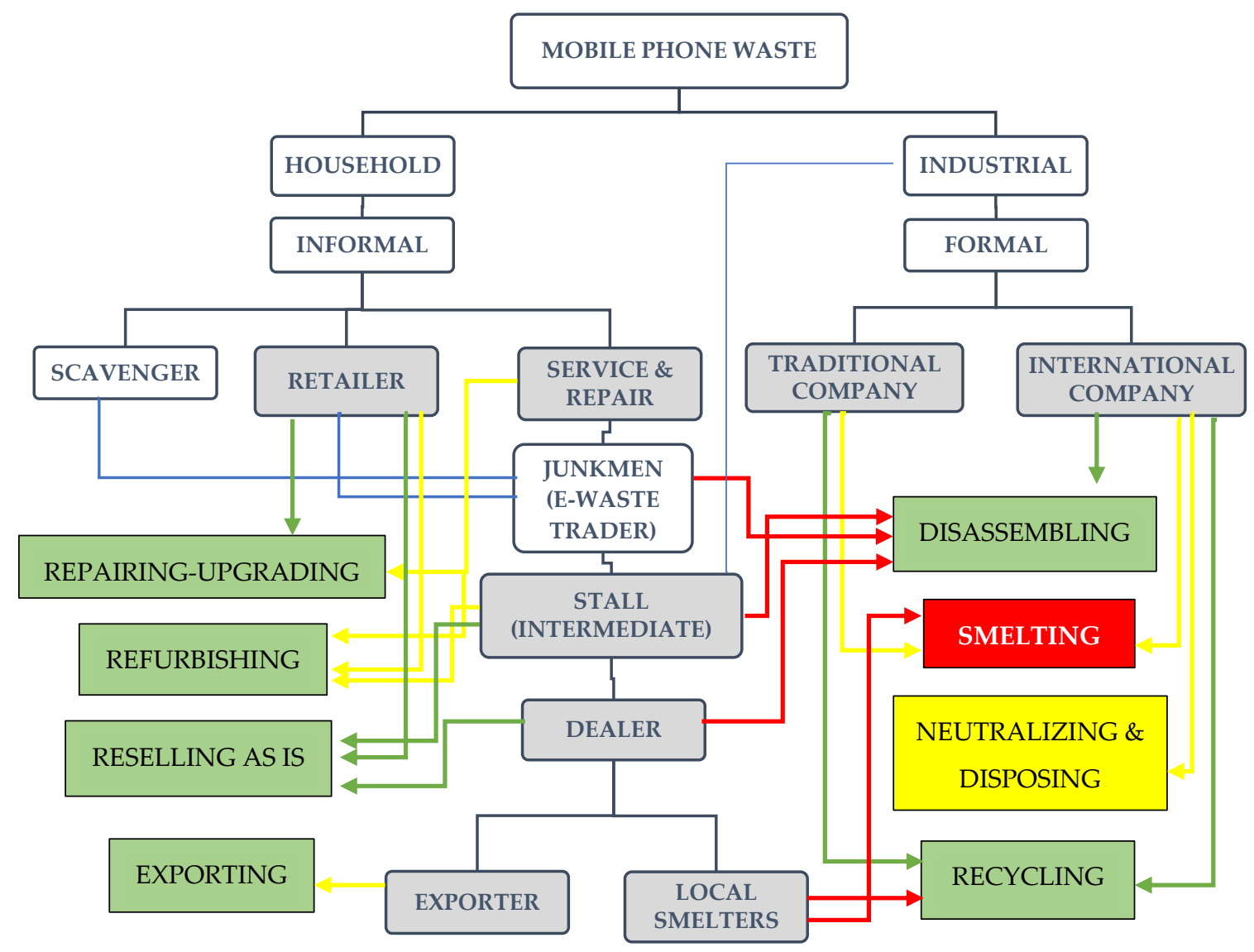

Figure 3. Current situation of mobile phone waste circulation in Indonesia.

\subsubsection{Intermediary Business Expectations}

Considering the difficulty of finding respondents who are willing to have an open discussion about their perspectives and expectations, as well as share their knowledge and experience, we decided to interview only eight actors as suggested by the key respondents. All respondents must have been involved in this field for more than ten years, except for the retailer and service center due to their high worker turnover. For establishing data validity, Table 2 describes each respondent profile by showing their activities, years of experience, and total time of interview.

By asking more than 24 questions, this research obtained 41 expectations of both formal and informal businesses. We intentionally separated these expectations based on the type of the businesses to describe their feedback tendency and to get a clear indication of the differences of expectations among them (Table 3). Almost all expectations relate to the government. Only 2 expectations are specifically directed to societies; that is: communities should change their mindset that not all used electronic products can be sold since the normalization costs of hazardous contents are higher than the price paid to them; and, societies must care more about their own e-waste [16]. They can participate to realize a $C E$ through implementing a sustainable product service system [31], because in addition to protecting the environment, they receive side income. We found some local smelters' expectations that are impossible to realize, i.e., obtaining a legal business permit, training on safe e-waste processing, 
and funding provision. We also found some unique suggestions, i.e., make this activity a local business and registered, and distribute components only for them.

Table 2. Respondents profile for in-depth interviews.

\begin{tabular}{|c|c|c|c|}
\hline Respondent & Years of Experience & Total Time Interview & Descriptions \\
\hline $\begin{array}{l}\text { International waste } \\
\text { management } \\
\text { company (R1) }\end{array}$ & 24 & 68 minutes & $\begin{array}{l}\text { Respondent } 1 \text { has been working since } 1994 \text { and } \\
\text { today he is a director of SEHQ and Production in an } \\
\text { international waste management company. } \\
\text { This company in Bogor - Indonesia which serves a } \\
\text { neutralizing and disposal hazardous waste to } \\
\text { landfill. He is a master in chemical engineering }\end{array}$ \\
\hline $\begin{array}{l}\text { Traditional waste } \\
\text { management } \\
\text { company (R2) }\end{array}$ & 10 & 87 minutes & $\begin{array}{l}\text { Respondent } 2 \text { is the president director of the waste } \\
\text { management company (home industry) and also as } \\
\text { the owner. This company has been operating since } \\
2008 \text { in Bekasi - Indonesia. This company is } \\
\text { dismantling and recycling used electronic products } \\
\text { which are converted to be a raw material for } \\
\text { other product }\end{array}$ \\
\hline $\begin{array}{l}\text { Dealer used } \\
\text { electronic goods (R3) }\end{array}$ & 11 & 47 minutes & $\begin{array}{l}\text { Respondent } 3 \text { is an owner of buying and selling a } \\
\text { used electronic business in dealer class who involved } \\
\text { more than } 10 \text { years in Jakarta. Firstly, he focused on } \\
\text { trading iron material, however, he changes his } \\
\text { business to WEEE dismantling since he is interested } \\
\text { in its benefit }\end{array}$ \\
\hline $\begin{array}{l}\text { Stall of used } \\
\text { electronic goods (R4) }\end{array}$ & 13 & 96 minutes & $\begin{array}{l}\text { Respondent } 4 \text { is the owner of a stall or intermediate. } \\
\text { He has been pursuing this field since } 2005 \text { in Depok - } \\
\text { West Java. Same with respondent } 3 \text {, this respondent } \\
\text { dismantles used electronic products and separates } \\
\text { each component and sells them to the dealer } \\
\text { (respondent 3) }\end{array}$ \\
\hline Exporter (R5) & 21 & 23 minutes & $\begin{array}{l}\text { Respondent } 5 \text { is an employee in exporter company } \\
\text { who has been working more than } 20 \text { years. HIs job is } \\
\text { handling goods receipt and export processing. } \\
\text { HIs company is in Jakarta - Indonesia }\end{array}$ \\
\hline Local Smelters (R6) & 16 & 46 minutes & $\begin{array}{l}\text { Respondent } 6 \text { is working in a local smelters business. } \\
\text { He is a specialist of mobile phone smelter. He has } \\
\text { been conducting this activity for more than } 15 \text { years. } \\
\text { Firstly, he has done by himself. However now, he has } \\
7 \text { workers. This business operates in Tasikmalaya - } \\
\text { West Java, Indonesia }\end{array}$ \\
\hline Retailer (R7) & 4 & 23 minutes & $\begin{array}{l}\text { Respondent } 7 \text { is a retailer. He has been selling mobile } \\
\text { phone both new and second hand in the last } 4 \text { years } \\
\text { in Bandung Electronic Centre - Indonesia }\end{array}$ \\
\hline $\begin{array}{l}\text { Service and } \\
\text { Repair (R8) }\end{array}$ & 7 & 18 minutes & $\begin{array}{l}\text { Respondent } 8 \text { is a service and repair in Bandung } \\
\text { Electronic Centre - West Java, Indonesia. He has } \\
\text { been working since } 2010 \text {. He repairs, upgrades a } \\
\text { broken mobile phone product and refurbishes it }\end{array}$ \\
\hline
\end{tabular}

Table 3. Summary of in-depth interview results.

\begin{tabular}{|c|c|c|}
\hline Key Questions to Be Addressed & Formal Group Answers & Informal Group Answers \\
\hline What is your business scope? & $\begin{array}{l}\text { R1: waste treatment and disposal solution } \\
\text { (dismantling, recycling, smelting, } \\
\text { and disposal/eco-landfill). } \\
\text { R2: Dismantling, recycling, and smelting to } \\
\text { get valuable material }\end{array}$ & $\begin{array}{l}\text { R3, R4: dismantling and selling } \\
\text { R5: exporting e-waste } \\
\text { R6: mining valuable material from WEEE } \\
\text { R7: selling as is and upgrading used } \\
\text { electronic products } \\
\text { R8: repairing, features upgrading, } \\
\text { and reselling }\end{array}$ \\
\hline $\begin{array}{l}\text { What is the main motivation in } \\
\text { running the business } \\
\text { (business principles) }\end{array}$ & $\begin{array}{l}\text { R1: minimize customer's environmental risk; } \\
\text { better living condition, healthier } \\
\text { communities, sustainable business activities, } \\
\text { besides economic benefit, and sound } \\
\text { reputation from local and international } \\
\text { parties; (reduce, reuse, recycle, recovery) } \\
\text { R2: profit, reduce health risks, } \\
\text { and environmental protection; (recycle, } \\
\text { recovery, renewable, eco-friendly) }\end{array}$ & $\begin{array}{l}\text { R3, R4, R5, R6, R7: profit } \\
\text { R8: profit and extend the span of life } \\
\text { electronic product }\end{array}$ \\
\hline $\begin{array}{l}\text { Do you pay attention to the safety } \\
\text { and health requirement? }\end{array}$ & $\begin{array}{l}\mathrm{R} 1, \mathrm{R} 2 \text { : Safety and health of an employee is } \\
\text { our priority }\end{array}$ & $\begin{array}{l}\mathrm{R} 3, \mathrm{R} 4, \mathrm{R} 5, \mathrm{R} 7, \mathrm{R} 8 \text { : Our job is not dangerous } \\
\mathrm{R} 6 \text { : this job is very profitable, there is no other } \\
\text { choice even though it is dangerous for us }\end{array}$ \\
\hline
\end{tabular}


Table 3. Cont

\begin{tabular}{|c|c|c|}
\hline Key Questions to Be Addressed & Formal Group Answers & Informal Group Answers \\
\hline $\begin{array}{l}\text { What is the proof that your } \\
\text { business concern with the } \\
\text { environment and } \\
\text { community's health? }\end{array}$ & $\begin{array}{l}\text { R1: compliance with Indonesia's regulations, } \\
\text { laboratory accreditation by the Ministry of } \\
\text { Environment and Forestry, produce synthetic } \\
\text { fuel from WEEE } \\
\text { R2: almost zero residues, using wastewater } \\
\text { scrubber, filtering air pollution by a } \\
\text { dust collector }\end{array}$ & $\begin{array}{l}\text { R3, R4, R5, R7, R8: reuse WEEE means } \\
\text { prevent littering the environment }\end{array}$ \\
\hline What is your business strategy? & $\begin{array}{l}\text { R1: provide cost-effective and customized } \\
\text { solutions by applying one-stop shop } \\
\text { R2: Open collaboration for the informal } \\
\text { group in providing the material }\end{array}$ & $\begin{array}{l}\text { R3, R4: mutual cooperation } \\
\text { R5: pricing strategy (higher than their } \\
\text { competitor i.e., stall and dealer) for stabilizing } \\
\text { the material supply } \\
\text { R6: clean and extra careful in processing } \\
\text { R7, R8: offering trade in scheme }\end{array}$ \\
\hline $\begin{array}{l}\text { What are the obstacles when } \\
\text { running this business especially } \\
\text { for used mobile phone handling? }\end{array}$ & $\begin{array}{l}\text { R1, R2: difficult to obtain the material, } \\
\text { difficult to face communities' perceptions, } \\
\text { unclear regulation, improper handling WEEE, } \\
\text { poor e-waste management, government } \\
\text { attitude, lack of infrastructure and regulation }\end{array}$ & $\begin{array}{l}\text { R3, R4: capital limitation, difficult to get a } \\
\text { business permit, illegal fees. } \\
\text { R5: illegal fees both from government } \\
\text { apparatus and private agency } \\
\text { R6: technology, business permit } \\
\text { R7, R8: capital limitation }\end{array}$ \\
\hline $\begin{array}{l}\text { Have you seen how other } \\
\text { countries handle } \\
\text { e-waste problems? }\end{array}$ & $\begin{array}{l}\text { R1: Yes, from Japan } \\
\text { R2: Yes, from Japan, Korea }\end{array}$ & $\begin{array}{l}\text { R3, R4, R6, R7, R8: never think about it } \\
\text { R5: Yes, China, Brazil, India }\end{array}$ \\
\hline $\begin{array}{l}\text { How big your willingness to } \\
\text { engage in SRL implementation }\end{array}$ & $\begin{array}{l}\text { R1: government must1) implement polluter } \\
\text { pay principle, 2) build the infrastructure of } \\
\text { WEEE regulation, management, system and } \\
\text { mechanism, 3) eradicate informal sector 4) } \\
\text { oblige societies to separate their own e-waste, } \\
\text { 4) educates communities and apparatus to be } \\
\text { more aware to the environment, 5) design } \\
\text { and applies punishment, 6) engage informal } \\
\text { group in collecting and distributing process } \\
\text { only, 7) create tax mechanism for managing } \\
\text { e-waste, and 8) collaborate among } \\
\text { government agencies } \\
\text { R2: Government must 1) socialize that profit } \\
\text { from recycling and smelting process not } \\
\text { comparable to cost of normalizing the } \\
\text { negative effect of the manual process, 2) } \\
\text { implement EPR by managing the recycling } \\
\text { fund from tax payment, 3) build significant } \\
\text { infrastructure } \\
\text { 4) implement a take-back system, } \\
\text { 5) avoid political interests and focus on the } \\
\text { environment, 6) develop control mechanism, } \\
\text { 7) localize of informal business, 8) strengthen } \\
\text { imports of electronic product by requiring the } \\
\text { importers more responsible to their own } \\
\text { e-waste, 9) encourage businesses to } \\
\text { minimizes residue and disposal activity, 10) } \\
\text { subsidize the needs of machines and } \\
\text { technologies, and 11) lead all stakeholders to } \\
\text { collaborate }\end{array}$ & $\begin{array}{l}\text { R3, R4: Government must 1) ensure there is } \\
\text { no e-waste incineration, 2) register all } \\
\text { businesses in e-waste processing, 3) localize } \\
\text { e-waste business in a certain place, 4) } \\
\text { distribute industrial and institution's WEEE } \\
\text { as well as from household to the registered } \\
\text { business, 5) apply zonation system in } \\
\text { distributing e-waste, 6) give a simplicity } \\
\text { business permit processing and } \\
\text { accompaniment model, 7) provide fund with } \\
\text { easy requirement and light installment, } \\
\text { 8) prohibit export e-waste, 9) subsidize the } \\
\text { needs of machine and technology, 10) set } \\
\text { e-waste processing for Indonesian business, } \\
\text { 11) regulate and force societies to throw } \\
\text { e-waste in a certain e-waste bin (drop-box), } \\
\text { R5: Government should 1) stabilize the } \\
\text { exchange rate, 2) eliminate illegal fees in } \\
\text { export processing, and 3) guarantee } \\
\text { convenience export processing, and, 4) reduce } \\
\text { the export duration } \\
\text { R6: Government should 1) give legal permit } \\
\text { for businesses of smelting WEEE, 2) give } \\
\text { training, 3) provide funding facilities to buy } \\
\text { machine and technology), 4) subsidize } \\
\text { machine procurement, 5) protect this business } \\
\text { since this is our main livelihood, and 6) give } \\
\text { used mobile phone from household to local } \\
\text { business only } \\
\text { R7: 1) stabilize product price, } \\
\text { 2) build second-hand market, 3) make } \\
\text { e-waste processing as a local business } \\
\text { R8: easy getting a spare part } \\
\text { R3: doubt to answer } \\
\text { R4, R8: big expectation } \\
\text { R6: refuse, impossible, do not believe to } \\
\text { government } \\
\text { R5, R7: no idea }\end{array}$ \\
\hline
\end{tabular}

The most common primary motivation of an informal business in conducting RL activity is to generate profit, since it represents their way of living. Meanwhile, formal businesses claim to focus more on environmental sustainability, although as a business they must also be concerned with economic benefits. Regardless of the business purpose, none want to be considered to be the main source of the e-waste problem, and all wish to maintain their reputation regarding environmental issues. People feel innocent if electronic products are often replaced since they use their own money $[5,6,20,34]$. Producers feel that they had contributed to increased economic growth through their sales and production [35]. They built some public facilities, e.g., drop-box and specific garbage trucks for used electronic products, representing their awareness of the environment. Intermediary businesses also 
feel that they had contributed to prevent environmental pollution via recycling activities [10]. In other words, a circular business model must be developed that considers not only profit, people, and the planet, but also reputation (SRL theory). The CBM can be used for SRL implementation but must be managed by the government as the highest authority $[9,10,19,34]$. The two groups mentioned the need for government subsidies to enlarge their capacity, ease of obtaining a business permit, clear rules to control household or individual behavior in disposing of their own e-waste, and concrete action to eliminate illegal fees. Clear regulation and e-waste process design standards are also needed by these groups. Lack of machinery, technology, and human resource capabilities must be a great concern for the government $[5,9,10,35]$. Localization of e-waste businesses is also suggested to facilitate component distribution, control these activities, and ensure the availability of buyers after the dismantling or recycling process. Therefore, the government needs to create and develop a CE in this business area [19], to provide significant potential benefits to businesses and still yield positive impacts for the environment and communities.

\subsubsection{Government Policies and Mobile Phone Waste Management in Indonesia}

Laws and regulations that have been made to handle the WEEE problem are Law No. 101 of 2014, article 1, verse 11-31 that concerns the management of e-waste. The Indonesian government also prohibits businesses from importing used electronic products, e-waste, and hazardous and toxic materials as shown by the Decision of the Ministry of Trade No. 229 of 1997 and the Basel Convention of 1989. The polluter-pays principle is also set out in Act No. 32 of 2009, article 2, verse (i) and Government Regulation No.18 of 1999, article 9, verse $(1,4,5)$. To reducing e-waste, the government assesses and controls the quality of products through the national standard of Indonesia (SNI), which enforces electronic products in the regulation of the Ministry of Industry No. 36 of 2017. The Indonesian government has formed an adjusted assessment institution in order to reinforce SNI application. The Ministry of Industry has machinery restructure and/or other equipment programs for small and medium industries. The Ministry of Industry regulation No. 20 of 2016 helps business improve the quality of their products. Thus, the procurement of machinery should no longer be a problem for converting e-waste to other valuable products. The government also encourages all businesses to reach green industry certification as specified in the rule of the Ministry of Industry No. 18 of 2016. To increase the number of new entrepreneurs, the Indonesian government launched a new business invention program to train businesses until they become established, under Act No. 20 of 2008. The government makes a serious effort to link and match small and medium enterprises with big industry to transfer knowledge of technology and improve their skills, as arranged in government rule No. 17 of 2013.

The laws and regulations mentioned above are only addressed toward manufacturers or formal business. The government has not created regulation for societies and informal business. From our previous study, we found some government expectations and, in the next subsection, we will discuss these clearly. The government delivers nine recommendations that should be conducted by intermediary businesses (formal and informal groups) so that they can maintain their activities in a more environmentally friendly manner.

\subsubsection{Government Expectations}

There are nine government expectations to be implemented in the SRL program by intermediary businesses [5], namely: (1) Eco-friendly process design. Formal and informal businesses must assess whether their activities do injure the environmental interest and communities' health. The consequences of polluting the environment are the willingness to convert e-waste into a valuable product with their own technology or pay a recovery process to the third party. However, most developing countries may not be able to implement the full concept of eco-friendliness without support from industrialized nations [38] and government. The differences in socio-cultural, economic, educational, political, technological, and infrastructural conditions between developed and developing 
countries pose serious challenges in copying e-waste management formulation. (2) After sales service is believed to be a good solution since it means an electronic product can be used for a longer period. (3) Recycling technology creation is the most important requirement for manufacturers of electronic goods because they generate a significant quantity of e-waste. Improper treatments, methods and tools, inadequate equipment, inaccurate process, and carelessness in determining the technology used could have fatal impacts $[1,7,9,14,15,32]$. (4) Standard equipment utilization is not important for most people in developing countries, and is difficult to implement. Exposures to the metals of a mobile phone used in daily life is around 0.1 to 7 micrograms per kilogram of body weight [39]. (5) Skill accreditation reflects human resource capability in e-waste processing. Many developed countries, such as Japan and Sweden, use this requirement as a first determination for awarding a legal business permit [21]. (6) Coaching for a small-medium enterprise can be one of the problem solutions. If this business has a well-organized operation, fulfills all requirements, and pays attention to operational standards, it could become a big employer for a densely populated country. Forbidding or competing with the abundant informal sector is useless [34]. It is better for the government to build cooperation with such businesses $[9,10,19,26]$. (7) Business alliances will be part of a sound strategy for the next step to realize sustainable reverse logistics implementation at every business level [19]. The traditional waste management company (R2) offered open collaboration with informal groups. However, this offer did not get a positive response from informal business since they were afraid their customers would be taken over. Cooperation between formal and informal business should be bridged by clear rules and regulation $[5,9,21]$. (8) Technology conversion must be provided by businesses-either producers or waste management companies—-through government support since it requires a high-cost technology [19]. Such businesses need government funding, and (9) business commitment, as the last recommendation, is definitely needed to realize the SRL program as a whole. Without commitment, we cannot guarantee the continuity of this program [5]. Usually, in many developing countries, businesses will be managed well and follow the applied rules if there is any strict control from a government officer [10]. When the officers are inconsistent, business are run arbitrarily and only focus on generating money.

\subsubsection{Customer Value Chain Analysis}

After determining the intermediary business expectations and summarizing the government expectations, rules, and regulations, this section maps their needs and values by using the customer value chain analysis (CVCA) depicted in Figure 4. This method was chosen because it was able to show the strict interactions among the actors. CVCA is able to meet the different needs and values of each party [13] in implementing the SRL program into an integrated activity. Further, we will use this mapping to find the engagement model of cooperation among all stakeholders for formulating the appropriate SRL program to handle the complexity of e-waste problems. 


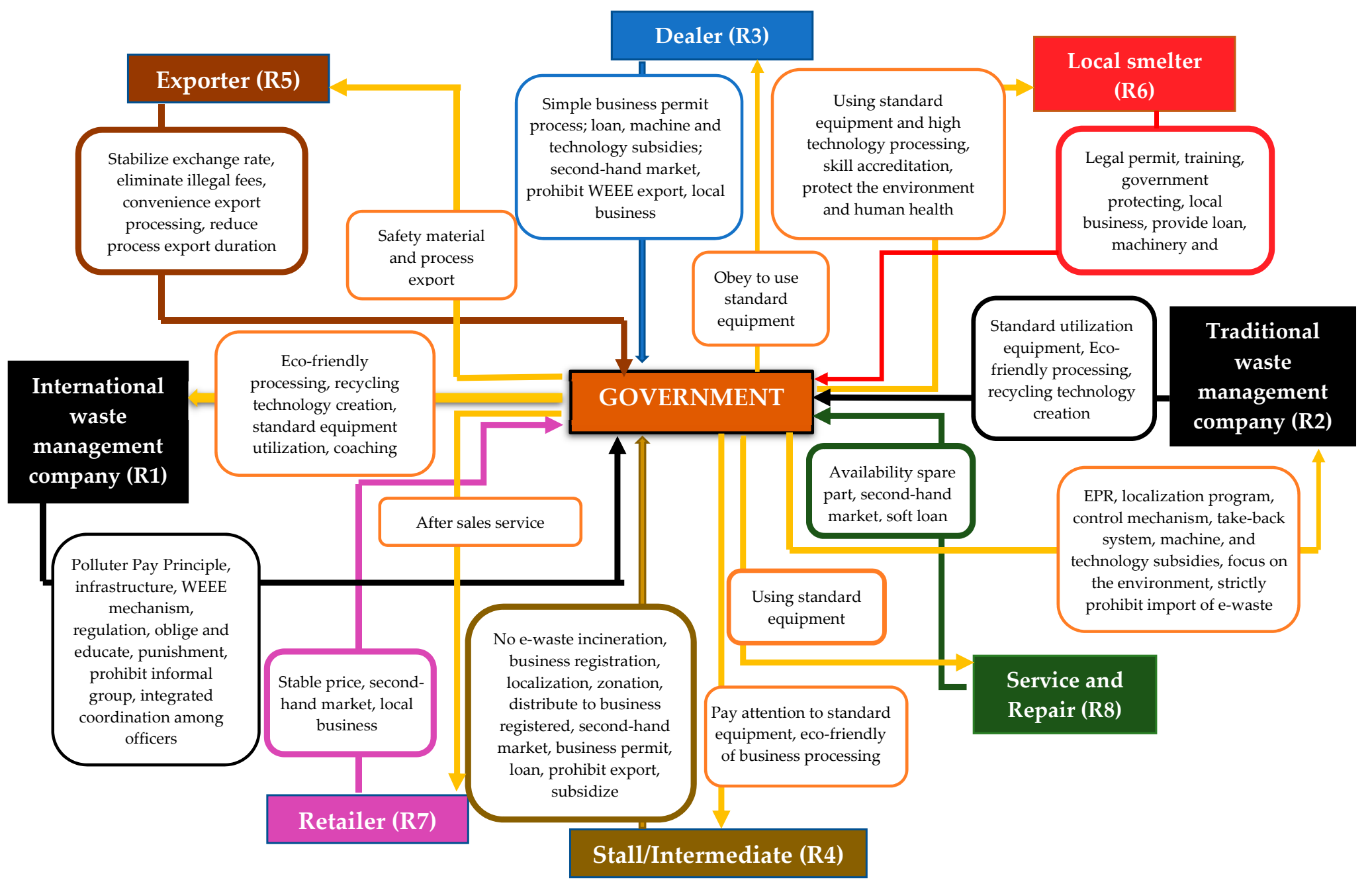

Figure 4. Customer value chain analysis for sustainable reverse logistics implementation. 
For understanding the needs and values expected by each actor, including the government, we explain the meaning of these arrows and boxes in Figure 4 one by one:

1. The expectations of the international waste management company (R1) for government, namely: implementing a polluter-pays principle for all electronic manufacturers; building infrastructure, such as e-waste banks, drop-box facilities, and specific trucks to transport e-waste; formulating a WEEE mechanism; establishing and campaigning for regulation; obliging and educating communities to obey the rule and policies; designing and applying punishment for people who violate; prohibiting illegal activity of informal group; and integrating coordination among officers from (at least) the four ministries in Indonesia, i.e., Ministry of Environment and Forestry, Ministry of Trade, Ministry of Industry, and Ministry of Finance. The government, in return, asks the international waste management company to apply eco-friendly processing, create a high technology for recycling, and to use standard equipment. We identified the expectation of local smelters (R6) for the international company (R1) to provide intensive training about good smelting processes, while the traditional waste management company expects $\mathrm{R} 1$ to avoid disposal activities in landfill areas since this activity is unsafe for the surrounding environment.

2. The traditional waste management company (R2) expects the government to oblige all manufacturers-either local or global — that generate toxic and hazardous wastes to implement EPR. Informal business activities must be localized for easy handling and controlling of the e-waste mechanism. Regulating and operating a take-back system, providing machinery and technology subsidies, and focusing on the environment must be part of the prioritized agenda since most people keep a used phone as a spare phone and are afraid of privacy disclosures [40]. Importers of electronic products who are not responsible for their e-waste should be strictly prohibited from operating in Indonesia. Meanwhile, the government has only one suggestion for this company, i.e., ensuring standard equipment utilization.

3. We named the dealer (R3) as the third actor. This dealer in reverse logistics activities is in charge of buying used mobile phone components from the dismantling activity of a stall. The dealer also looks for WEEE material from an auction organization. For joining in an auction event, a participant must have legal entities as a payment requirement. However, almost all actors in informal groups, including the dealer, do not have a legal entity, therefore the dealer expects simplicity in obtaining a business permit. In addition, they also need a soft loan to develop their business and to buy a high technology machine. The dealer also really hopes that the government prohibits exporting of WEEE, especially of used mobile phone components. If possible, the government should establish this business as a local business only for indigenous people since this business is their only source of income.

4. The stall (R4) expects the government to register all informal businesses in the reverse chain as legal businesses. Registered businesses will thus get a guaranteed supply of materials without competing with formal businesses, and have no reason to burn and export e-waste since it yields significant profit. They suggested that the government implements a zoning system. Localization of these businesses in a particular area is also one of their hopes for obtaining components easily. Business licenses are needed to recognize their existence, so they propose a simple procedure for legality. For developing their businesses, they need loans and government subsidization of machinery and technology. The government should prohibit the export of e-waste and make these businesses local. Meanwhile, dealers and stalls are required to comply with minimum standards, especially for implementing eco-friendly business processes.

5. An exporter (R5) of WEEE or mobile phone waste expects the government to stabilize the exchange rate, eliminate illegal export fees, enhance convenience of export processing, and reduce the export process duration. Meanwhile, the government suggested exporters ship safe material only so their activity does not create a negative image from the perspective of other countries.

6. As for the dealer and stall, local smelters (R6) expect a legal permit to facilitate their work. Training into safely mining the valuable material from e-waste is also much needed by them. 
They hope government facilitates this so they can they operate without damage. They need protection from illegal inspection by some individual government officers which often leads to illegal levies. They do not want to run their businesses secretly; on the contrary, they expect the government to recognize their existence. Moreover, making this business a local business is also much expected by local smelters, in addition to soft loans and subsidies for machinery and technology to develop their business. The government is actually very worried about their activity since their behavior suggests they neglect to use standard equipment. On the contrary, the smelters think their inability to operate these businesses safely, lack of high-technology machinery ownership, and low skill of human resources to protect the environment and human health from their activities are government responsibilities.

7. We identified three retailer's expectations (R7), namely, the government must: stabilize the price of electronic products to maintain circulation and facilitate the determination of prices in the reverse chain; build a special second-hand market; and make this business a local business. The government requires retailers to run after-sales service programs, including for second-hand or refurbished products.

8. Service and repair outlets (R8) expect stabilization of spare part availability so they can realize their goals to maximize electronic product usage. In addition, the government is expected to provide soft loans for business to utilize purchasing discounts if they buy in large quantities. Although they have few roles, we must recognize that their activities are able to reduce disposal of second-hand electronic products. The government encourages this group to use standard equipment, such as gloves, masks, and a specific machine when operating their businesses. Four respondents-dealer, stall, retailer and repair service outlet-propose that the government build a specific second-hand market for used electronic products. This market facilitates CBM development that controls e-waste circulation by adding the span of the product's life while also providing an economic benefit.

\subsection{Engagement Model of Government and Intermediary Businesses to Implement Sustainable Reverse Logistics}

Finding an engagement model is the final step in this research. We cannot equalize all levels of engagement, the nature of the relationships, and the types of communications for each model. Therefore, this section regards and accurately compares the two actors' expectations before determining its type of engagements (Figure 5). Generally, we propose the empowerment, collaboration, and participation model by considering the QBL concept with the six balancing constructs [5], i.e., supportable, equitable, capable, bearable, alignable, and suitable (Figure 1).

We suggest the empowerment and collaboration model to engage the international waste management company (R1) with the government. The form of empowerment is integrated with the company's strategy and the government program for processing and converting e-waste into a valuable product. Its strategy and operation must cover government policies and rules, such as providing cost-effective and customized solutions by applying one-stop shopping from solid and liquid waste treatment, converting waste to energy, and serving eco-landfills. The type of collaboration between them is a joint program in the process of e-waste collection from households by providing special trucks and facilitating a drop box program. As part of their corporate social responsibilities (CSR), this company can act as a partner of government to facilitates a training program for informal businesses. Certainly, this company needs community recognition that they are capable of protecting the environment and societies' health from e-waste (i.e., capable construct). To avoid placing responsibility on each other, a collaborative platform must be determined clearly. 


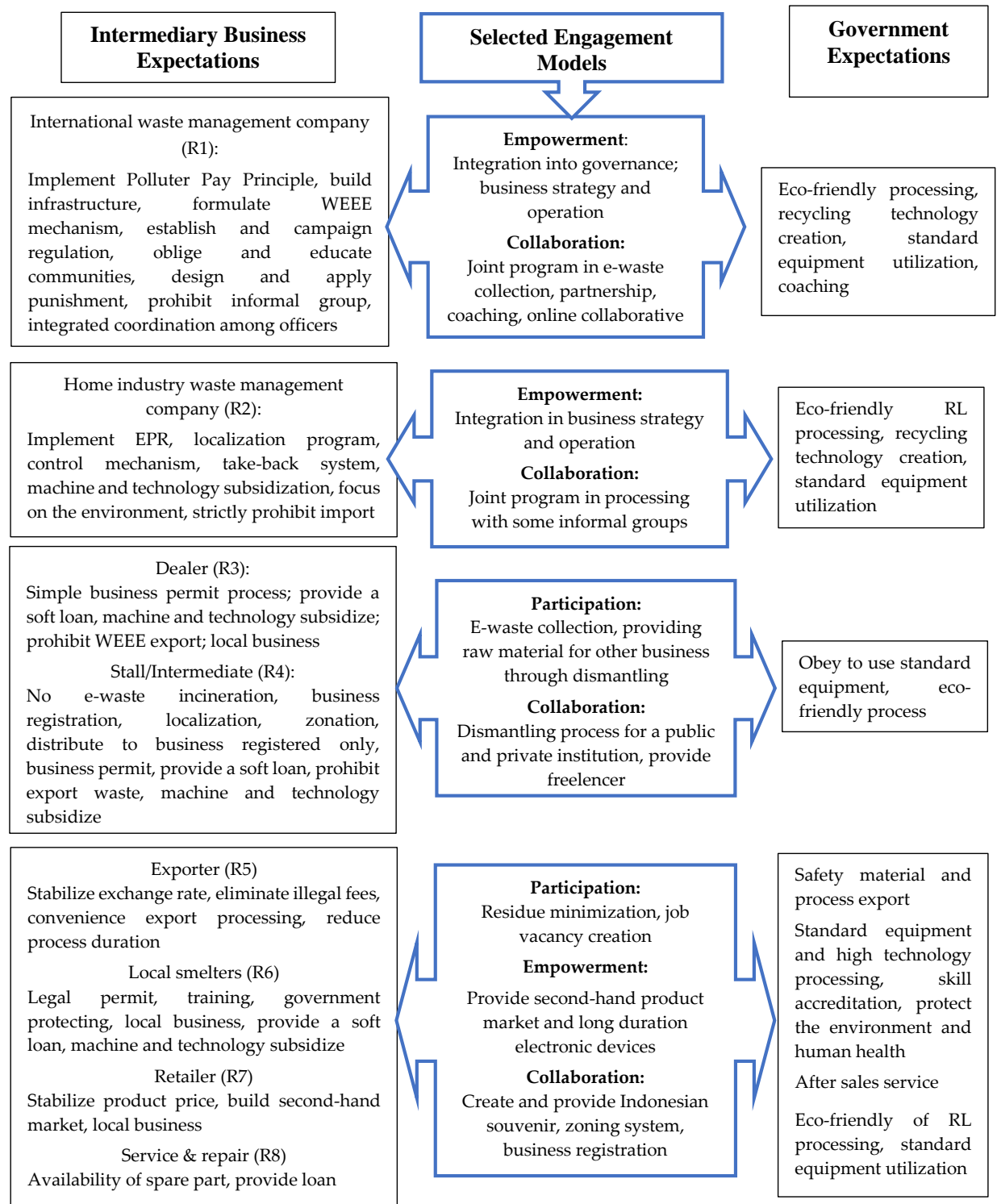

Figure 5. Proposed engagement model of government and intermediary businesses in SRL implementation.

Different from R1, the traditional waste management company (R2) prefers a joint program in e-waste processing rather than providing training for informal businesses as a form of collaboration model. They provide a place for dismantling and recycling activities by informal groups so that government can control their activities easily. The advantage of the presence of the informal group in the waste management company is that it is easy to obtain the material and quickly carry out the dismantling process. Eco-friendly RL processing, development of recycling technology, and utilizing standard equipment form the integrated business strategy for gaining a good reputation. Therefore, this company has shown its ability and responsibility for balancing profit, the planet, people, and also reputation through a direct integrated operation to the government program (capable and bearable constructs).

Participation and collaboration are regarded as the appropriate engagement model for the dealer (R3) and the stall (R4) with the government. They support the government in protecting the environment by collecting e-waste while looking for profit (supportable construct) [1]. By collecting e-waste, and dismantling and separating the components based on their types (aluminum, plastics, copper, $\mathrm{PCB})$, the dealer and stall have participated in the SRL program and helped protect the 
environment [1]. R3 and R4 also collaborate with government by providing freelancers to handle e-waste from government offices and private institutions, such as light bulbs, cables, monitors, and other electronic products, that cannot be used any more. Furthermore, the government is expected to manage e-waste distribution only for accredited and registered recycling businesses.

We suggest three types of engagement models, i.e., empowerment, collaboration, and participation, for engagement of exporters (R5), local smelters (R6), retailers (R7), and repair and service outlets (R8) with government. They participate in minimizing e-waste, especially from mobile phones, by buying components from a dealer or stall for further processing, such as exporting, refurbishment, and reconditioning. The government can empower exporters to decrease e-waste by sending it to other countries that have high capability technology for converting. Retailers prevent second-hand mobile phone from being quickly discarded by reselling it to others. Service and repair businesses extend the life of many kinds of electronic products [41], upgrading features and repairing or replacing broken parts. However, although local smelters use inappropriate methods, they try to recover many valuable assets, such as gold, aluminum, and copper, from e-waste. Besides participation and empowerment, a collaboration between smelters and government must be realized through finding a creative way to minimize disposal activity. Developing creative industries by using e-waste material to make Indonesian souvenirs is one sustainable business model archetype [42], similar to that of Japan, which used it for making medals at an Asian Games event. This activity provides some balanced advantages for the planet (environment) and people (humans), thereby applying the CE principle. While preserving the environment, this activity increases social welfare (equitable construct).

Retailers (R7) and service and repair businesses (R8) can be empowered to provide used mobile phone products [14] for reselling in the second-hand product market. This activity creates new jobs for people with low education and without specific skills (equitable). Countries with many infertile areas can choose recycling activities as the main livelihoods for their societies. By purchasing e-waste from densely populated countries, they can receive money through mining gold and copper. This means that SRL activity can support increasing the community's welfare (supportable construct). Meanwhile, operating this activity safely is a government responsibility. If some businesses in Indonesia can export e-waste to other countries, such as China, Germany, Hungary, India, and Malaysia, it means there are many valuable components in it. The government is responsible for finding a safe method and technology [42] as a form of its collaboration, so that business goals are aligned with the interests of the planet and people (alignable construct). Collaboration between local smelters and the government in realizing the implementation of SRL is in the form of providing facilities and infrastructure. The government provides a place for zoning systems and the smelters and recyclers must be willing to be localized and to follow the zoning regulations. They must be willing to be registered for conducting control mechanisms. By registering them, the government can predict the quantity of facilities and infrastructure that must be built.

Finally, the government must collaborate with all actors of the intermediary businesses to minimize disposal activities. The government, together with intermediary businesses, must generate some creative ways to turn e-waste into energy. One creative breakthrough has been made by the first respondent. This company (R1) has succeeded in converting e-waste into fuel as a substitute for coal used by the cement plant. Some developed countries, such as Japan and Norway, use e-waste as the road paving [6]. Shared distribution modes can be copied for mass e-waste collection [18,32] to increase business efficiency in the reverse chain. These creative ways show that collaboration models generate a good image for business and government, while enhancing community welfare at the same time (suitable construct).

\section{Conclusions and Further Research}

Mobile phone production is abundant in many developing countries $[5,6,29,40]$, including Indonesia. This is caused by increasing economic growth, which directly increases community purchasing power. In addition, consumers' consumptive behavior means mobile phone sales in 
developing countries are higher than in developed countries [1,4]. The average Indonesian consumer uses their mobile phone for less than 3 years, and almost 15 million mobile phones are retired annually [34]. This behavior has generated a significant amount of mobile phone waste [36], while the government, as the highest authority, has not been ready to face this problem. Poor e-waste management happens in many developing countries, and low levels of education, unemployment, and poverty make e-waste an opportunity to generate profit for informal businesses. These grow and spread evenly in all regions of Indonesia and dominate the market for used electronic products. Some formal businesses, both local and global, that fulfill the requirements to operate e-waste businesses, are unable to compete with the large number of informal businesses to acquire used mobile phones.

We identified six main actors in the informal group, i.e., dealers, stalls, local smelters, exporters, retailers, and repair service businesses. We noted that almost all ignore safety procedures in conducting RL activities, such as recycling, reusing, reselling as is, refurbishing, and repairing, and including smelting and dismantling, although they claimed that their activities have an environmental purpose. Environmental pollution happens in many places and is uncontrolled. Society health is disturbed since business activities only focus on profit. Actions to prevent environmental pollution are conducted only for maintaining their reputation because they do not want to be blamed as the root cause of this damage. Hence, we believe that reputation will be a new facet of sustainability theory for the cases of developing countries. Not many studies have been conducted on the sustainability topic including reputation concepts. There has also been little research on RL that emphasizes the sustainability concept, as it is considered to be equal to protecting the environment. Some researchers $[9,10,15,17]$ concluded that reverse logistics could be a good solution for the e-waste problem. We clarified that this concept is insufficient without emphasizing the balance of each element (profit, planet, people, reputation), especially for developing countries with the same characteristics as Indonesia. We proposed six constructs to balance the QBL elements, i.e., supportable, equitable, capable, alignable, bearable, and suitable. Therefore, we believed that research about e-waste management in developing countries requires terminology of sustainable reverse logistics (SRL), instead of reverse logistics (RL). In terms of the contribution to theory development, this research has strengthened the literature related to the reverse logistics concept.

It is impossible for e-waste management to be undertaken only by a government. An engagement model between stakeholders must be formulated. For formulating this model, we must understand all stakeholders' expectation. Therefore, this research used customer value chain analysis for mapping expectations. We found 41 important factors were expected by intermediary businesses. We emphasized seven expectations that are really wanted by informal businesses, i.e., legal business entity, soft loan provision, local business establishment, business registration, simplicity of obtaining a business permit, distribution scheme (only for registered business), and zoning system. We also found a unique expectation, i.e., building some special markets for second-hand electronic products that facilitate the building of a proper, complete SRL mechanism. This is very surprising because informal businesses want the government to recognize their existence and engage them to overcome e-waste problems. Eradicating their enormous number will be impossible. Competing with them is also useless [34] and will even cause new problems [9]. Therefore, this research investigated the engagement models, and we chose empowerment, collaboration, and participation as the models.

The provided models should assist a government in designing regulations for e-waste businesses, and especially informal businesses; however, it requires further examination due to the limitations of this research. Thus, future research will be conducted by distributing a closed-ended questionnaire to intermediary businesses to confirm their level of agreement with these constructs (their expectations) and these engagement types. We hope the selected constructs can be used as a standard for measuring sustainable reverse logistics performance and as guidance to control activities in the reverse chain.

Author Contributions: G.Y., A.A., H.M. conceived and designed research; H.M. collected the data; G.Y., H.M. Analyzed the data; H.M. wrote the paper. 
Funding: This research was funded by BUDI-DN (LPDP) scholarship from The Ministry of Finance and The Ministry of Research Technology and Higher Education Republic Indonesia.

Acknowledgments: This study would not have been possible without support material and non-material from LPDP scholarship from The Ministry of Finance and The Ministry of Research Technology and Higher Education. The author would like to thank and appreciate the invaluable constructive views and comments by referees especially for Dr. Haruki Agustina as the key respondent from the Ministry of Environment and Forestry-Republic Indonesia, Wawan Budiawan (PT. Mukti Mandiri Lestari), and Ir. Syarif Hidayat (SHEQ PT. Pershada Pamunah Limbah Industry).

Conflicts of Interest: The authors declare no conflict of interest.

\section{References}

1. Jang, Y.C.; Kim, M. Management of used \& end-of-life mobile phone in Korea: A review. Resour. Conserv. Recycl. 2010, 55, 11-19. [CrossRef]

2. Andarani, P.; Goto, N. Potential e-waste generated from households in Indonesia using material flow analysis. J. Mater. Cycle Waste Manag. 2014, 16, 306-320. [CrossRef]

3. Global Smartphone Sales Increase positively, One Merck is Lost Kompas.com. Gartner Research, c2018. Available online: http:/ / www.kompas.com (accessed on 31 August 2018).

4. Martinho, G.; Magalhaes, D.; Pires, A. Consumer behavior with respect to the consumption and recycling of smartphone and tablets: An exploratory study in Portugal. J. Clean. Prod. 2017, 156, 147-158. [CrossRef]

5. Maheswari, H.; Yudoko, G.; Adhiutama, A. Theory building of quattro bottom line approach for sustainable reverse logistics from government perspective: The Indonesia evidence. Adv. Sci. Technol. Eng. Syst. J. 2018, 3, 83-98. [CrossRef]

6. Maheswari, H.; Yudoko, G.; Adhiutama, A. Stakeholder engagement model in quattro helix model for mobile phone reverse logistics in Indonesia: A conceptual framework. In Proceedings of the IOP Conference Series: Materials Science and Engineering, Belitung, Indonesia, 7-9 November 2017. [CrossRef]

7. Ezechi, E.H.; Nwabuko, C.G.; Enyinnaya, O.C. Municipal solid waste management in Aba, Nigeria: Challenges and prospects. Environ. Eng. Res. 2017, 22, 231-236. [CrossRef]

8. Yin, J.; Gao, Y.; Xu, H. Survey and analysis of consumers' behavior of waste mobile phone recycling in China. J. Clean. Prod. 2013, 1-9. [CrossRef]

9. Damanhuri, E. The role of informal collector of recyclable waste and used goods in Indonesia. Post-Cons. Waste Rec. Opt. Prod. 2012. [CrossRef]

10. Budijati, S.M. Model of Reverse Logistics Management: Close Loop and Opened Loop as well as Consumer Behavior Accommodation [Dissertation]; UGM: Yogyakarta, Indonesia, 2016.

11. Indonesia Mobile User Based on Location. Available online: https:/ /www.statista.com/statistics/274659/ forecast-of-mobile-phone-users-in-indonesia/ (accessed on 27 January 2019).

12. The Generation at Cinangka-Bogor village threaten idiot, Sudarno H. m.liputan6.com, c2018. Available online: https:/ / www.liputan6.com (accessed on 11 October 2018).

13. Donaldson, T.; Preston, L.E. The stakeholder theory of the corporation: Concepts, evidence, and implication. Acad. Manag. Rev. 1995, 20, 65-91. [CrossRef]

14. Kleindofer, P.R.; Singhal, K.; Wassenhove, L.N.V. Sustainable operations management. Prod. Oper. Manag. 2005, 14, 482-492. [CrossRef]

15. Thierry, M.; Salomon, M.J.V.N.; Nunen, J.V.; Wassenhove, L.N.V. Strategic issue in product recovery management. Calif. Manag. Rev. 1995, 37, 114-135. [CrossRef]

16. De Brito, M.P.; Dekker, R. A framework for reverse logistics. ERIM Rep. Ser. 2003, 1-23. [CrossRef]

17. Emmet, S.; Sood, V. Green Supply Chain; A John Wiley and Sons, Ltd.: Publication, UK, 2010; p. 144.

18. Lakatos, E.S.; Cioca, L.; Dan, V.; Ciomos, A.O.; Crisan, O.A.; Barsan, G. Studies and investigation about the attitude towards sustainable production, consumption, and waste generation in line with circular economy in Romania. Sustainability 2018, 10, 865. [CrossRef]

19. Lewandowski, M. Designing the business models for circular economy-Towards the conceptual framework. Sustainability 2016, 8, 43. [CrossRef]

20. Maheswari, H.; Yudoko, G.; Adhiutama, A. Towards sustainable reverse logistics: A conceptual framework of quattro bottom line approach. In Proceedings of the 2017 IEEE International Conference on Industrial Engineering and Engineering Management (IEEM), Singapore, 10-13 December 2017; pp. 1377-1381. 
21. Ardi, R.; Leisten, R. Assessing the role of informal sector in WEEE managing system: A system dynamics approach. Waste Manag. 2016, 57, 3-16. [CrossRef] [PubMed]

22. AA1000 SES. Accountability 1000 Stakeholder Engagement Standard 2015. Available online: https://www. accountability.org/wp-content/uploads /2016/10/AA1000SES_2015.pdf (accessed on 27 January 2019).

23. Eisenhardt, K. Agency theory: An assessment and review. Acad. Manag. Rev. 1989, 14, 532-574. [CrossRef]

24. Heller, K.; Price, R.H.; Reinhartz, S.; Riger, S.; Wandersman, A.; D'Aunno, T.A. Psychology and Community Change: Challenges of the Future; Brooks/Cole: Monterey, CA, USA, 1984.

25. Wilcox, D. Community Participation and Empowerment: Putting Theory into Practice; RRA Notes Issue 21; IIED: London, UK, 1994; pp. 78-82.

26. Agranoff, R.; Mc Guire, M. Collaborative Public Management: New Strategy for Local Government; Georgetown University Press: Washington, DC, USA, 2003; p. 35.

27. Huxham, C.; Vangen, S. Key themes in the Management of relationship between public and non-profit organization. Int. J. Public Sect. Manag. 1994, 9, 5-17. [CrossRef]

28. Munt, R. Building collaboration, stronger families learning exchange. Bulletin 2003, 6-8. Available online: http:/ / citeseerx.ist.psu.edu/viewdoc/download?doi=10.1.1.195.3561\&rep=rep1\&type=pdf (accessed on 27 January 2019).

29. Nnorom, I.C.; Ohakwe, J.; Osibanjo, O. Survey of willingness of residents to participate in electronic waste recycling in Nigeria-A case study of mobile phone recycling. J. Clean. Prod. 2009, 17, 1629-1637. [CrossRef]

30. Neuman, W.L. Social Research Method: Qualitative and Quantitative Approaches, 6th ed.; Pearson International Edition: New York, NY, USA, 2006.

31. Hobson, K.; Lynch, N.; Lilley, D.; Smalley, G. Systems of practice and the circular economy: Transforming mobile phone product service systems. Environ. Innov. Soc. Trans. 2018, 26, 147-157. [CrossRef]

32. Tanskanen, P. Electronics Waste: Recycling of Mobile Phones; INTECH Open Access Publisher: Rijeka, Croatia, 2012.

33. Vereecke, A.; Muylle, S. Performance improvement through supply chain collaboration in Europe. Int. J. Prod. Manag. 2006, 26, 1176-1198. [CrossRef]

34. Kissling, R.; Coughlan, D.; Fitzpatrick, C.; Boeni, H.; Luepschen, C.; Andrew, S.; Dickenson, J. Success factors and barriers in re-use of electrical and electronic equipment. Resour. Conserv. Recycl. 2013, 80, $21-31$. [CrossRef]

35. Yudoko, G. Integrated municipal solid waste planning and management (IMSWPM) in developing countries: A conceptual framework. J. Technol. Manag. 2007. Available online: http://journal.sbm.itb.ac.id/index.php/ mantek/article/view/34 (accessed on 27 January 2019).

36. Borthakur, A.; Govind, M. Emerging trends in consumers' e-waste disposal behavior ad awareness: A worldwide overview with special focus on India. Resour. Conserv. Recycl. 2017, 117, 102-113. [CrossRef]

37. Definition and Facts, Britannica.com. Available online: https://www.britannica.com/technology (accessed on 3 September 2018).

38. Nwachukwu, M.A.; Feng, H.; Achilike, K. Integrated studies for automobile wastes management in developing countries; In the concept of environmentally friendly mechanic village. J. Environ. Monit. Assess. 2011, 178, 581-593. [CrossRef] [PubMed]

39. Wen, X.; Xiaohua, Z. The new process in integrated waste management in China. In Proceedings of the 2008 IEEE International Symposium on Electronics and the Environment, San Francisco, CA, USA, 19-22 May 2008.

40. Penners, O.; Semeijn, J.; Riel, A.C.R.; Lambrechts, W. Life cycle extension of mobile phone-An exploration with focus on the end-consumer. Cent. Eur. Rev. EC Manag. 2018, 2, 7-37. [CrossRef]

41. Polák, M.; Drapálová, L. Estimation of end of life mobile phone generation: The case study of the Czech Republic. Waste Manag. 2012, 32, 1583-1591. [CrossRef] [PubMed]

42. Bocken, N.M.P.; Short, S.W.; Rana, P.; Evans, S. A literature and practice review to develop sustainable business model archetypes. J. Clean. Prod. 2014, 65, 42-56. [CrossRef]

(C) 2019 by the authors. Licensee MDPI, Basel, Switzerland. This article is an open access article distributed under the terms and conditions of the Creative Commons Attribution (CC BY) license (http:/ / creativecommons.org/licenses/by/4.0/). 